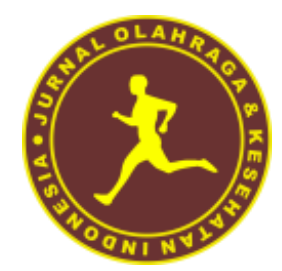

\title{
PROFIL KONDISI FISIK, TEKNIK, DAN PSIKIS ATLET SEPAK TAKRAW
}

\author{
Soeandi Malik Pratama ${ }^{1}$, Ibrahim Wiyaka ${ }^{2}$ \\ ${ }^{12}$ Universitas Negeri Medan, Sumatera Utara, Indonesia, 20221 \\ *Coressponding Author: soeandimalikpratama16.048@gmail.com
}

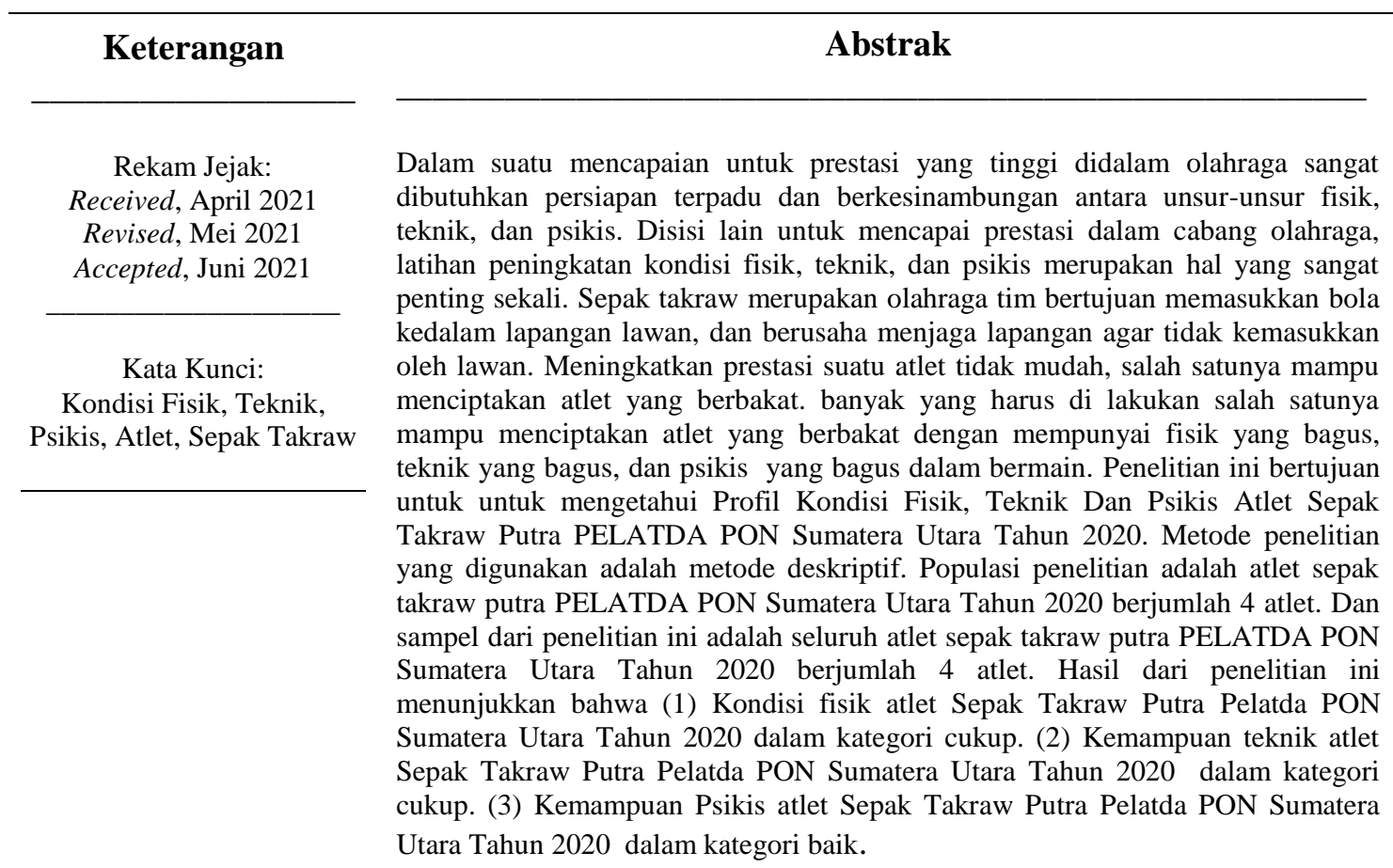

Copyright (c) 2020

Jurnal Olahraga \& Kesehatan Indonesia 


\section{PENDAHULUAN}

Sasaran dalam suatu pembinaan olahraga adalah mencapai prestasi yang maksimal. Di dalam dunia olahraga, prestasi merupakan salah satu faktor dalam keberhasilan pembangunan olahraga. Dengan kata lain prestasi olahraga merupakan indikator yang dapat digunakan secara langsung untuk melihat status atau tingkat pencapaian dan keberhasilan dalam olahraga. Ada beberapa komponen yang menentukan tercapainya prestasi tinggi dalam olahraga prestasi yaitu keadaan kesejahteraan pelatih dan atlet perlu perhatian dari pembina/pengurus induk cabang olahraga. Untuk melihat dan mengevaluasi hasil pembinaan, perlu memberikan uji coba dengan melakukan kompetisi dan try out baik di dalam negeri maupun di luar negeri dengan tujuan mengukur kemampuan bertanding/berlomba dan kematangan sebagai pembentukan teknik, fisik, dan mental bertanding.

Dalam mencapai prestasi yang tinggi didalam olahraga dibutuhkan persiapan terpadu dan berkesinambungan antara unsur-unsur fisik, teknik, dan psikis. Di sisi lain untuk mencapai prestasi dalam cabang olahraga sepak taktaw, latihan untuk peningkatan kemanpuan kondisi fisik, teknik, dan psikis merupakan hal yang sangat penting, karena kondisi fisik, teknik, dan psikis yang baik akan membantu atlet untuk mempermudah melakukan dan menguasai teknikteknik dasar. Begitu pula halnya dalam sepak takraw, komponen-komponen fisik, teknik, dan psikis berperan penting dalam melakukan teknik sepakan, main kepala, mendada, memaha, membahu, serangan atau smash, dan menahan atau block. Meraih prestasi yang maksimal membutuhkan usaha dan kerja keras, berupa latihan yang terencana, terukur dan berkesinambungan. Latihan yang dilakukan harus sesuai dengan kebutuhan cabang olahraga yang dilakukan dan unsur fisik, teknik, dan psikis yang dominan, sehingga unsur-unsur fisik itulah yang dibangun dan ditingkatkan melalui proses latihan. Selain itu, apabila kondisi fisik atlet dalam keadaan baik, maka atlet akan lebih cepat menguasai teknik-teknik gerakan yang dilatihkan.

Aktifitas fisik salah satunya berolahraga saat ini menjadi prioritas utama guna menjaga kesehatan maupun kebugaran jasmani. Olahraga menjadi sarana pelepas stres, penunjang kepercayaan diri dan acuan sebagai gaya hidup. Olahraga ini bertujuan agar atlit lebih aktif dan meningkatkan kemampuan dan keterampilan yang dimiliki atlet yang ada di PSTI Sumatera Utara . Salah satu cabang olahraga yang ditawarkan dalam kegiatan PSTI Sumatera Utara adalah sepaktakraw. Menurut Sudrajat Prawirasaputra (2000: 19), ada 3 keterampilan dasar sepaktakraw secara umum, yaitu keterampilan manipulatif, keterampilan non lokomotor, dan keterampilan lokomotor. Sepak takraw adalah salah satu cabang olahraga yang menuntut keterampilan yang tinggi dalam permainannya.

Dapat ditarik kesimpulan bahwa seluruh Sepak Takraw ialah merupakan olahraga tim yang terdiri dari dua lawan pemain di tiap tim yang bertujuan memasukkan bola kedalam lapangan lawan, dan serta berusaha untuk menjaga lapangan agar tidak kemasukkan oleh lawan. Tim yang lebih banyak memasukkan bola lapangan lawan lah yang jadi pemenangnya agar pada prestasi atlet dalam sepak takraw. Oleh karena itu, peneliti tertarik untuk menarik penelitian dengan judul "Profil Kondisi Fisik, Teknik Dan Psikis Atlet Sepak Takraw Putra Pelatda PON Sumatera Utara Tahun 2020".

\section{METODE}

Arikunto (2013:172) menyatakan bahwa "Populsi adalah keseluruhan subjek penelitian". Populasi dalam penelitian ini adalah Atlet Sepak Takraw Putra Pelatda PON tahun 2020 yang berjumlah 4 orang. Teknik pengambilan sampel pada penelitian ini adalah total sampel yaitu: keseluruhan anggota populasi menjadi sampel. Adapun sampel dalam penelitian ini adalah seluruh Atlet Sepak Takraw Putra Pelatda PON berjumlah 4 Orang. Sesuai dengan permasalahan dan tujuan penelitian yang telah diuraikan sebelumnya, bahwa penelitian ini dilakukan bertujuan untuk m etahui Profil Kondisi Fisik, Teknik Dan Psikis Atlet Sepak 
Takraw Putra Pelatda Pon Sumatera Utara Tahun 2020. Adapun metode penelitian ini menggunakan deskriftip dengan teknik tes dan pengukuran sesuai dengan cabang Sepak Takraw.

Penelitian ini bertujuan untuk mengungkap Profil Kondisi Fisik, Teknk, Psikis Atlet Sepak Takraw Putra Pelatda PON Sumatera Utara Tahun 2020.

- Instrumen Tes Kondisi Fisik (Harsuki, 2003)

- Tes Lari 30 Meter

- Tes Loncat Tegak

- Tes Lari 300 Meter

- Tes Sit Up

- Tes Shuttle Run 4 x 5 Meter

- Tes Sit \& Reach

- Tes Lari Bleep Test

- Instrumen Tes Teknik Sepak Takraw (Nurhasan, 2001)

- Tes Servis

- Tes Kontrol Bola

- Tes Operan

- Tes Smash

- Instrumen Tes Psikis Olahraga (James Tangkudung, 2018)

- Tes Komitmen

- Tes Kepercayaan diri

\section{HASIL \& PEMBAHASAN}

Pertama untuk atlet Kurnia dengan item Lari 30 meter mendapat waktu 4.03 dengan nilai 4, Kedua untuk item Loncat Tegak mendapat raihan 62 dengan nilai 3, Ketiga untuk item Lari 300 Meter mendapat waktu 48.32 dengan nilai 3, Keempat untuk item Sit-up mendapat skor 68 dengan nilai 4, Kelima untuk item Shutle Run mendapat waktu 14.07 dengan nilai 3, Keenam untuk item Sit And Reach medapat raihan 31 dengan nilai 4, Ketujuh untuk item Lari Bleep Tes mendapat waktu 46,20 dengan nilai 2. Berdasarkan hasil analisis data kondisi fisik, Kurnia mendapat nilai 23 dengan nilai rata-rata 3,28 Kurang. Kemudian, untuk kemampuan teknik dengan teknik servis mendapat hasil 178.02 dengan nilai 10, Kedua untuk teknik sepak sila mendapat hasil 62 dengan nilai 10, Ketiga untuk teknik Passing mendapat hasil 11 dengan nilai 5, Keempat untuk teknik Smash mendapat hasil 93.6 dengan nilai 4. Berdasarkan hasil analisis data kondisi fisik, Kurnia mendapat nilai 29 dengan nilai rata-rata 7.25 kategori cukup. Maka dari itu disarankan agar lebih meningkatkan lagi latihan yang mengarah pada peningkatan kemampuan teknik, terprogram dan memiliki intensitas. Kemudian untuk kondisi psikis atlet dengan variabel komitmen dan kepercayaan diri berdasarkan hasil tabulasi data terhadap jawaban dari 25 butir pertanyaan atlet bernama Kurnia dapat disimpulkan bahwa atlet berada pada kondisi psikis yang baik dengan kategori atlet memiliki komitmen dan kepercayaan diri yang tinggi.

Untuk atlet Yudha pertama dengan item Lari 30 meter mendapat waktu 4.16 dengan nilai 4, Kedua untuk item Loncat Tegak mendapat raihan 85 dengan nilai 4, Ketiga untuk item Lari 300 Meter mendapat waktu 49.68 dengan nilai 3, Keempat untuk item Sit-up mendapat skor 66 dengan nilai 4, Kelima untuk item Shutle Run mendapat waktu 14.21 dengan nilai 3, Keenam untuk item Sit And Reach medapat raihan 24 dengan nilai 3, Ketujuh untuk item Bleep Tes mendapat waktu 43.00 dengan nilai 2. Berdasarkan hasil analisis data kondisi fisik, Yudha mendapat nilai 23 dengan nilai rata-rata 3,28 Kurang. Kemudian untuk kemampuan teknik pertama dengan teknik servis mendapat hasil 117.67 dengan nilai 9, Kedua untuk teknik sepak sila mendapat hasil 58 dengan nilai 10, Ketiga untuk teknik Passing mendapat hasil 15 dengan nilai 7, Keempat untuk teknik Smash mendapat hasil 95.67 dengan nilai 5. Berdasarkan hasil analisis data kondisi fisik, Yudha mendapat nilai 31 dengan nilai rata-rata 7.75 kategori cukup. 
Maka dari itu disarankan agar lebih meningkatkan lagi latihan yang mengarah pada peningkatan kemampuan teknik, terprogram dan memiliki intensitas. Kemudian untuk kondisi psikis atlet dengan variabel komitmen dan kepercayaan diri berdasarkan hasil tabulasi data terhadap jawaban dari 25 butir pertanyaan atlet bernama Yudha dapat disimpulkan bahwa atlet berada pada kondisi psikis yang baik dengan kategori atlet memiliki komitmen dan kepercayaan diri yang tinggi.

Untuk atlet Nanda pertama dengan item Lari 30 meter mendapat waktu 4.13 dengan nilai 4, Kedua untuk item Loncat Tegak mendapat raihan 62 dengan nilai 3, Ketiga untuk item Lari 300 Meter mendapat waktu 49.41 dengan nilai 3, Keempat untuk item Sit-up mendapat skor 56 dengan nilai 4, Kelima untuk item Shutle Run mendapat waktu 13.75 dengan nilai 3, Keenam untuk item Sit And Reach medapat raihan 34 dengan nilai 4 Ketujuh untuk item Lari Bleep Tes mendapat waktu 45.90 dengan nilai 2. Berdasarkan hasil analisis data kondisi fisik, Nanda mendapat nilai 23 dengan nilai rata-rata 3,28 Kurang. Kemudian untuk kemampuan teknik servis mendapat hasil 100,42 dengan nilai 6, Kedua untuk teknik sepak sila mendapat hasil 55 dengan nilai 10, Ketiga untuk teknik Passing mendapat hasil 14 dengan nilai 7, Keempat untuk teknik Smash mendapat hasil 99.49 dengan nilai 5. Berdasarkan hasil analisis data kondisi fisik, Nanda mendapat nilai 28 dengan nilai rata-rata 7 kategori cukup. Maka dari itu disarankan agar lebih meningkatkan lagi latihan yang mengarah pada peningkatan kemampuan teknik, terprogram dan memiliki intensitas. Kemudian untuk kondisi psikis atlet dengan variabel komitmen dan kepercayaan diri berdasarkan hasil tabulasi data terhadap jawaban dari 25 butir pertanyaan atlet bernama Nanda dapat disimpulkan bahwa atlet berada pada kondisi psikis yang baik dengan kategori atlet memiliki komitmen dan kepercayaan diri yang tinggi.

Untuk atlet Reza pertama dengan item Lari 30 meter mendapat waktu 4.17 dengan nilai 4, Kedua untuk item Loncat Tegak mendapat raihan 66 dengan nilai 3, Ketiga untuk item Lari 300 Meter mendapat waktu 47.28 dengan nilai 3, Keempat untuk item Sit-up mendapat skor 67 dengan nilai 4, Kelima untuk item Shutle Run mendapat waktu 13.15 dengan nilai 4, Keenam untuk item Sit And Reach medapat raihan 24 dengan nilai 3, Ketujuh untuk item Lari Bleep Tes mendapat waktu 44.65 dengan nilai 2. Berdasarkan hasil analisis data kondisi fisik, Reza mendapat nilai 23 dengan nilai rata-rata 3,28 Kurang. Kemudian hasil kemampuan teknik pertama dengan teknik servis mendapat hasil 101.45 dengan nilai 6, Kedua untuk teknik sepak sila mendapat hasil 59 dengan nilai 10, Ketiga untuk teknik Passing mendapat hasil 11 dengan nilai 5, Keempat untuk teknik Smash mendapat hasil 99.49 dengan nilai 5. Berdasarkan hasil analisis data kondisi fisik, Reza mendapat nilai 26 dengan nilai rata-rata 6.5 kategori cukup. Maka dari itu disarankan agar lebih meningkatkan lagi latihan yang mengarah pada peningkatan kemampuan teknik, terprogram dan memiliki intensitas. Kemudian untuk kondisi psikis atlet dengan variabel komitmen dan kepercayaan diri berdasarkan hasil tabulasi data terhadap jawaban dari 25 butir pertanyaan atlet bernama Reza dapat disimpulkan bahwa atlet berada pada kondisi psikis yang baik dengan kategori atlet memiliki komitmen dan kepercayaan diri yang tinggi.

Berdasarkan hasil penelitian tersebut dapat ditemukan beberapa alasan yang kemungkinan mempengaruhi tingkat kondisi fisik atlet Sepak Takraw Putra Pelatda PON SUMATERA UTARA Tahun 2020 yang diantaranya adalah faktor-faktor pribadi dan kelompok seperti kesiapan, intensitas latihan, program latihan, gizi, ekonomi, mental, mood dan faktorfaktor lainnya yang membutuhkan aktifitas fisik. Untuk itu disarankan agar menjaga kondisi fisik ketika akan melakukan latihan yang telah terprogram oleh pelatih.

Kecepatan atlet dapat meningkat jika diberikan latihan yang mengarah pada peningkatan kondisi fisik kecepatan. Latihan kecepatan yang dapat diberikan seperti interval sprint, lari akselerasi, down hill, up hill. Begitupun dengan daya ledak otot tungkai dapat ditingkatkan dengan pemberian latihan daya ledak otot tungkai yang dapat dilakukan dengan latihan poliometrik seperti latihan lompat-lompat ditangga dengan waktu,latihan melompat dada dan lain sebagainya yang berhubungan dengan melompat. Kemudian untuk meningkatkan daya 
tahan otot perut para atlet dapat diberikan latihan yang mengarah pada peningkatan daya tahan otot perut seperti sit-up dan back-up. Agar anaerobik atlet dapat meningkat, maka disimpulkan perlu diberikan latihan yang mengarah pada peningkatan kondisi fisik daya tahan anaerobik seperti lantihan interval training, fartlek, speed play, sprint-sprint pendek dengan waktu yang telah ditentukan.

Kelincahan atlet dapat meningkat jika diberikan latihan yang mengarah pada peningkatan kondisi fisik daya tahan anaerobik seperti lantihan yang mengarah pada peningkatan kondisi fisik kelincahan seperti lari zig-zag, latihan kombinasi seperti terlentang,jongkok, lompat dada lalu sprintdan shuttle run. Kelentukan atlet dapat dipertahankan atau ditempah agar semakin meningkat, untuk itu perlu diberikan latihan yang mengarah pada peningkatan kondisi fisik daya tahan kelentukan seperti melakukan peregangan statis, dinamis, pasif, dan PNF. Kemudian untuk meningkatkan aerobic atlet, maka perlu diberikan latihan yang mengarah pada peningkatan kondisi fisik daya tahan aerobik, seperti lantihan yang mengarah pada peningkatan kondisi fisik daya tahan aerobik seperti fartlek, interval, dan cross country.

Dari hasil pengolahan data yang telah diuraikan dapat disimpulkan bahwa kemampuan teknik altet Sepak Takraw Putra Pelatda PON Sumatera Utara Tahun 2020 secara umum dalam kategori cukup. Untuk teknik servis atlet Sepak Takraw Putra Pelatda PON Sumatera Utara Tahun 2020 berada pada kategori cukup. Untuk itu agar kemampuan servis atlet dapat meningkat, dapat disimpulkan bahwa perlu diberikan latihan yang mengarah pada peningkatan teknik servis. Latihan servis dapat dilakukan dengan latihan split, memukul bola yang di lambungkan teman dan bola yang digantung.

Untuk teknik sepak sila, atlet Sepak Takraw Putra Pelatda PON Sumatera Utara Tahun 2020 berada pada kategori cukup. Untuk itu agar kemampuan sepak sila lebih baik lagi dapat ditingkatatkan melalui latihan sepak sila individu,berpasangan dan berkelompok. Untuk teknik Passing, atlet Sepak Takraw Putra Pelatda PON Sumatera Utara Tahun 2020 pada kategori kategori cukup. Untuk meningkatkan kemampuan passingatlet, maka disimpulkan bahwa perlu diberikan latihan yang mengarah pada peningkatan kemampuan passing,seperti lantihan yang mengarah pada peningkatan passing seperti passing dengan sasaran tembok yang di beri angka, passing berpasangan, dan lain sebagainya. Untuk teknik Smash, atlet Sepak Takraw Putra Pelatda PON Sumatera Utara Tahun 2020 berada pada kategori cukup. Untuk meningkatkan kemampuan Smash atlet, maka disimpulkan bahwa perlu diberikan latihan yang mengarah pada peningkatan kemampuan Smash, seperti latihan memukul bola yang dilambungkan, bola yang digantung dan latihan lain sebagainya seperti melompat smabil memutarkan pinggang.

Bila dilihat dari kemampuan teknik berdasarkan posisi pemain terjadi perbedaan hasil yang signifikans, artinya kemampuan erat hubungannya dengan spesialisasi posisi dengan kemampuan dominan teknik yang dipergunakan dalam bermain. Kurnia yang posisi feeder memeliki kemampuan passing lebih baik daripada Yudha, Nanda dan Reza. Yudha posisi smash memiliki kemampuan smash yang lebih baik daripada Kurnia dan Nanda. Nanda posisi tekong memeliki kemampuan servis lebih baik daripada Kurnia, Yudha, dan Reza. Sedang Reza posisi smash, memeliki kemampuan smash lebih baik daripada Kurnia, Yudha, dan Nanda.

Berdasarkan hasil penelitian tersebut dapat ditemukan beberapa alasan yang kemungkinan mempengaruhi tingkat teknik kemampuan khusus atlet Sepak Takraw Putra Pelatda PON SUMATERA UTARA Tahun 2020 yang diantaranya adalah faktor-faktor pribadi, kelompok dan lingkungan seperti kesiapan, mental, intensitas latihan, program latihan, gizi, ekonomi, dan faktor-faktor lainnya yang membutuhkan aktifitas fisik. Bukan hanya beberapa faktor di atas yang mempengaruhi kondisi fisik dan kemampuan khusus/teknik khusus, akan tetapi dari segi program latihan yang ada pada saat ini pun tidak mencukupi untuk dapat membuat atlet memiliki prestasi yang baik, baik tingkat Propinsi maupun tingkat Nasional.

Selain faktor yang disebutkan diatas dalam bertanding juga ditentukan oleh kesiapan mental atau kematangan psikis, sebab sering terjadi seorang pemain atau sebuah tim yang memiliki fisik, teknik dan taktik bagus kalah bertanding karena lemah secara psikis. Dalam 
penelitian ini keseluruhan sampel berada pada tingkat komitmen dan kepercayaan diri yang tinggi. Itu disebabkan oleh kesadaran diri atlet dan motivasi diri juga dari pelatih serta orangorang yang berpengaruh dalam lingkungan atlet tergolong tinggi. Olahraga tidak hanya dilakukan untuk mencapai manfaat kesehatan saja, tetapi juga dapat dijadikan sarana untuk meraih prestasi atau kesuksesan. Dalam perjalanan meraih prestasi, seorang atlet tidak hanya membutuhkan kemampuan fisik dan teknik, namun kemampuan psikologis juga diperlukan. Atlet pemula atau junior yang kurang memiliki pengalaman bertanding sering mengalami kendala tersebut. Kepiawaian pelatih untuk merotasi pemain akan memiliki dampak yang postif terhadap kemampuan fisik, skill, dan kematangan psikis pemain. Selain itu, pelatih dan juga diri atlet secara pribadi diharapkan mampu memompa semangat dan kepercayaan diri pemain dengan berbagai cara agar pemain memiliki kematangan psikologi yang baik. Dengan memiliki kematangan psikologi yang baik maka sebuah tim akan mampu menunjukkan kekompakan dan kebersamaan yang baik sebagai faktor keberhasilan dalam pertandingan.

\section{SIMPULAN}

Dari data hasil tes pengukuran dan pembahasan dari hasil penelitian maka dapat disimpulkan bahwa kondisi fisik atlet Sepak Takraw Putra Pelatda PON Sumatera Utara Tahun 2020 dalam kategori rendah, kemampuan teknik atlet Sepak Takraw Putra Pelatda PON Sumatera Utara Tahun 2020 dalam kategori cukup, dan kemampuan psikis atlet Sepak Takraw Putra Pelatda PON Sumatera Utara Tahun 2020 dalam kategori tinggi.

\section{DAFTAR PUSTAKA}

Achmad Sofyan Hanif. (2018). Kepelatihan Dasar Sepak Takraw. Jakarta: Raja Pers.

Ahmad Jamalong \& Asry Syam. (2014). Teknik Dasar Permainan Sepak Takraw. Yogyakarta: Ombak.

Anindra Guspa \& Tuti Rahmi (2014). Hubungan Antara Persepsi Terhadap Financial Reward Dengan Komitmen Kerja Pada Atlet. Jurnal RAP UNP, 5 (1), 1-11

Apta Mylsidayu. (2015). Psikologi Olahraga. Jakarta: Bumi Aksara.

Aramelia. (2008). Bermain Sepak Takraw. Semarang: Aneka Ilmu.

Arikunto. (2006). Prosedur Penelitian Suatu Pendekatan Praktek. Jakarta: PT. Rineka Cipta.

Boyke Mulyana. (2013). Hubungan konsep diri, komitmen, dan motivasi berprestasi dengan prestasi renang gaya bebas. Jurnal UPI

Darwis Ratinus. (1992). Olahraga Pilihan Sepak Takraw. Padang: Pengulu Basa.

Fitri Yulianto \& H. Fuad Nashori. (2006). Kepercayaan Diri Dan Prestasi Atlet Tae Kwon Do Daerah Istimewa Yogyakarta. Jurnal UNDIP, 3 (1)

Furqon. (2009). Statistika Terapan Untuk Penelitihan. Bandung: Alfabeta.

Harsono. (1988). Coaching dan Aspek-aspek Psikologi dalam Coaching. Jakarta: Tambak Kesuma.

Harsuki. (2003). Perkembangan Olahraga Terkini. Jakarta: PT Raja Grafindo Persada.

Husdarta. (2011). Psikologi Olahraga. Bandung: Alfabeta.

Husni Thamrin. (2008). Olahraga Pilihan Sepak Takraw. Yogyakarta: Universitas Negeri Yogyakarta.

Imran Akhmad. (2013). Dasar-Dasar Melatih Fisik Olahragawan. Medan: Unimed Press.

Iyakrus. (2012). Permainan Sepak Takraw. Palembang: Unsri Press.

James Tangkudung \& Apta Mylsidayu. (2017). Mental Training: Aspek-Aspek Psikologi Dalam Olahraga. Jakarta: Cakrawala Cendekia.

James Tangkudung. (2018). Sport Psychometrics: Dasar-dasar dan Instrumen Psikometri. Jakarta: PT Raja Grafindo Persada.

Komarudin. (2017). Psikologi Olahraga Latihan Keterampilan Mental dalam Olahraga Kompetitif. Bandung: PT Remaja Rosdakarya.

Nazir. (2014). Metode Penelitian. Bogor: Ghalia Indonesia. 
Nurhasan. (2001). Tes dan Pengukuran Dalam Pendidikan Jasmani.

Rick Engel. (2010). Dasar-Dasar Sepak Takraw. Bandung: ASEC Internastional.

Sajoto. (1988). Pembinaan Kondis Fisik dalam Olahraga. Jakarta: FPOK-IKIP Semarang.

Sudibyo Setyobroto. (1989). Psikologi Olahraga. Jakarta: PT Anem Kosong Anem.

Sudjana. ( 2012). Metode Statistika. Bandung: Tarsito.

Sudradjat Pawirasaputra \& Lingling Usli. (2001). Pembelajran Permainan Sepak Takraw. Jakarta: Direktoral Jenderal Pendidikan Dasar dan Menengah.

Sugiono. (2018). Metode Penelitihan Kuantitatif, Kualitatif dan R\&D.

Suharsimi Arikunto. (2010). Prosedur Penelitian Suatu Pendekatan Praktik. Jakarta: Rineka Cipta.

Suryono, dkk. (2002). Instrumen Pemanduan Bakat Sepak Takraw. Jakarta: PB Prestasi.

Tudor Bompa. (1988). Theory and Methodologi of Training. Canada: Mocaic Pres.

Widiastuti. (2017). Tes dan Pengukuran Olahraga. Jakarta: PT Raja Grafindo Persada.

Yahya Eko Nopiyanto \& Dimyati. (2018). Karakteristik Psikologis Atlet Sea Games Indonesia Ditinjau Dari Jenis Cabang Olahraga Dan Jenis Kelamin. Jurnal UNY, 6 (1), 69-76 